\title{
Menentukan Variabel Prediktor bagi Kinerja Guru PAI
}

\author{
Ikhrom
}

IAIN Walisongo Semarang

Email: ikhrom69@yahoo.com

\begin{abstract}
This paper attempts to analyze the influence of supervision of Islamic Education (PAI), compensation, competence, and motivation to work on PAI teacher performance. The result of multiple linear regression analysis concluded that all four aspects are jointly significant affect the performance of teachers PAI. Partial regression test results explained that the supervision and competence of significant influence while compensation and motivation influenced but not significant. Based on the model test found that supervision direct impact on performance. Supervision has a direct influence scores greater than the indirect effect. Compensation does not affect the performance directly but through the direct influence of motivation because scores compensation is smaller than the indirect effect. Competence directly influence performance significantly due to the direct influence of competence scores greater than the indirect effect scores.
\end{abstract}

Keywords: supervision, compensation, competence, motivation

\begin{abstract}
Abstrak
Tulisan ini bertujuan untuk menganalisis pengaruh supervisi pengawas PAI, kompensasi, kompetensi, dan motivasi kerja terhadap kinerja guru PAI. Hasil uji analisis regresi linier berganda disimpulkan bahwa keempat aspek tersebut secara bersama-sama berpengaruh secara siginifikan terhadap kinerja guru PAI. Hasil uji regresi secara parsial menjelaskan bahwa supervisi dan kompetensi berpengaruh signifikan, sementara kompensasi dan motivasi berpengaruh tetapi tidak signifikan. Berdasar pada uji model ditemukan, bahwa supervisi pengawas berpengaruh secara langsung terhadap kinerja. Supervisi memiliki skor pengaruh langsung lebih besar dari skor pengaruh tidak langsung. Kompensasi berpengaruh terhadap kinerja secara tidak langsung tetapi melalui motivasi karena skor pengaruh langsung kompensasi lebih kecil dari pengaruh tidak langsung. Kompetensi berpengaruh langsung terhadap kinerja secara signifikan karena skor pengaruh langsung kompetensi lebih besar dari skor pengaruh tidak langsung.
\end{abstract}

Kata kunci: supervisi, kompensasi,kompetensi, motivasi. 


\section{A. Pendahuluan}

Paparan ini menelusuri lebih jauh mengenai kinerja guru Pendidikan Agama Islam (PAI) pada Sekolah Dasar (SD) se-Kota Semarang dibidik melalui variabel supervisi, kompensasi, kompetensi, dan motivasi kerja. Materi ini kiranya mendesak, mengingat beberapa hal. Pertama, sebagai staf pengajar Fakultas Ilmu Tarbiyah dan Keguruan (FITK) dan asesor Sertifikasi Guru PAI, penulis merasa punya tanggung jawab moral karena para guru PAI mendapatkan sertifikat pendidik melalui Pendidikan dan Latihan Profesi Guru (PLPG) di Lembaga Pendidikan Tenaga Kependidikan (LPTK) 206 IAIN Walisongo Semarang. Kedua, secara teoritik, para guru lulusan PLPG seharusnya mengalami peningkatan pada aspek kompetensi yang selanjutnya berpengaruh terhadap kinerjanya. Ketiga, dampak lulusan PLPG adalah mendapatkan sertifikat pendidik, yang selanjutnya berdampak pada pencairan tunjangan profesi. Pada giliran berikutnya, penerimaan tunjangan profesi seharusnya berdampak positif terhadap kinerjanya. Kelima, sertifikasi pengawas ternyata juga melalui PLPG yang diselenggarakan LPTK 206. Supervisi sudah seharusnya juga dilibatkan sebagai salah satu variabel prediktor bagi kinerja guru.

Secara sederhana, kompensasi merupakan aspek penting dalam mempengaruhi motivasi dan kinerja guru. Guru merupakan ujung tombak peningkatan mutu pendidikan. Ini berarti terdapat hubungan kuat antara mutu pendidikan dengan mutu guru. Mutu guru dipengaruhi kualitas kompensasi yang diterimanya. Simpulan ini didukung sebuah teori, bahwa terdapat hubungan yang jauh lebih kuat antara kepuasan kerja dan kinerja karyawan. ${ }^{1}$ Atas dasar teori tersebut dapat dirumuskan, semakin tinggi kompensasi kepuasan yang diterima guru, semakin tinggi pula motivasi dan kinerjanya.

Faktor lain yang mempengaruhi kinerja guru PAI adalah kompetensi keguruan. Ini berangkat dari sebuah asumsi, tanpa kompetensi sulit bagi seseorang untuk mampu melakukan pekerjaannya dengan baik. Tanpa kompetensi, semangat kerja pun sulit untuk dibangun, apalagi ditingkatkan. Dalam teori harapan (expectancy theory) dikatakan, "in general, motivation to behave in a certain way is greatest when the individual believes that the ability

${ }^{1}$ Fred Luthans, Organizational Behaviour, $10^{\text {th }}$ Edition, (Yogyakarta: Penerbit Andi,2006), hlm. 246. 
exists to perform at the desired level". ${ }^{2}$ Teori Mitchel penting diangkat untuk menguatkan fungsi kompetensi bagi guru. Teori tersebut menjelaskan bahwa kinerja guru sama dengan kemampuan untuk melakukan tugas-tugas yang dibebankan kepadanya dikalikan dengan motivasi untuk melakukan tugas-tugas tersebut. Teori itu mengisyaratkan, motivasi tidak berpengaruh terhadap kompetensi seseorang. Motivasi hanya dapat membuat kompetensi semakin efektif berfungsi. Motivasi tidak akan berguna untuk memacu orang yang tidak memiliki kompetensi. Tulisan ini bertujuan untuk menjawab pertanyaan, adakah variabel supervisi, kompensasi, kompetensi, dan motivasi kerja berpengaruh terhadap kinerja?

\section{B. Metode Penelitian}

Tulisan ini didasarkan pada hasil penelitian atas para guru PAI SD se-Kota Semarang. Dari data yang diperoleh dari Kepala Seksi Pendidikan Agama Islam di Sekolah (PAIS) pada Kantor Kementerian Agama Kota Semarang (2013), total jumlah guru PAI se-Kota Semarang adalah 627 orang PNS dan non-PNS, mereka tersebar di 16 kecamatan, jumlah inilah yang dijadikan populasi penelitian. Penentuan sampel penelitian dilakukan dengan menggunakan tabel Isaac and Michael. Dengan menggunakan tabel diperoleh besaran sampel, yakni 227. Besarnya jumlah sampel tiap kecamatan berbeda-beda. Adapun pengambilan sampel digunakan teknik proporsional random. Artinya, penentuan responden tiap kecamatan dilakukan secara acak. Yang penting kuota tiap kecamatan harus terpenuhi. Sumber data diperoleh melalui angket, analisis data menggunakan model regresi linier berganda, teknik olah data menggunakan bantuan SPSS 17.00. Adapun hipotesis bahasan ini adalah ada pengaruh signifikan variabel supervisi, kompensasi, kompetensi, dan motivasi kerja terhadap kinerja guru PAI.

\section{Hasil Penelitian}

Pembahasan ini ditujukan untuk menjawab pertanyaan utama, yakni apakah variabel supervisi, kompensasi, dan kompetensi berpengaruh terhadap motivasi kerja guru PAI? Sekaligus untuk membuktikan kebenaran hipotesis yang diajukan. Pembahasan didasarkan pada output hasil analisis regresi linier berganda.

\footnotetext{
${ }^{2}$ Wayne K. Hoy dan Cecil G. Miskel, Educational Admintration, Theory,
} Research, and Practice, (United State: McGrawhill, Inc, 1991), hlm. 179. 
Model Summary

\begin{tabular}{ccccc}
\hline Model & $\mathrm{R}$ & $R$ Square & $\begin{array}{c}\text { Adjusted } R \\
\text { Square }\end{array}$ & $\begin{array}{c}\text { Std. Error of the } \\
\text { Estimate }\end{array}$ \\
\hline 1 &, 769 (a) &, 592 &, 584 & 7,647 \\
\hline
\end{tabular}

aPredictors: (Constant), Motivasi, Supervisi, Kompensasi, Kompetensi

$\operatorname{ANOVA}(\mathbf{b})$

\begin{tabular}{llcrccc}
\hline Model & $\begin{array}{c}\text { Sum of } \\
\text { Squares }\end{array}$ & df & $\begin{array}{c}\text { Mean } \\
\text { Square }\end{array}$ & F & Sig. \\
\hline 1 & Regression & 18825,552 & 4 & 4706,388 & 80,479 & ,000(a) \\
\hline Residual & 12982,510 & 222 & 58,480 & & \\
\hline & Total & 31808,062 & 226 & & & \\
\hline
\end{tabular}

aPredictors: (Constant), Motivasi, Supervisi, Kompensasi, Kompetensi bDependent Variable: Kinerja

Coefficients(a)

\begin{tabular}{|c|c|c|c|c|c|c|}
\hline & \multirow[t]{2}{*}{ Model } & \multicolumn{2}{|c|}{$\begin{array}{l}\text { Unstandardized } \\
\text { Coefficients }\end{array}$} & $\begin{array}{l}\text { Standard- } \\
\text { ized } \\
\text { Coeffi- } \\
\text { cients }\end{array}$ & $\mathrm{t}$ & Sig. \\
\hline & & B & $\begin{array}{c}\text { Std. } \\
\text { Error }\end{array}$ & Beta & B & Std. Error \\
\hline \multirow[t]{5}{*}{1} & $($ Constant $)$ & 29,121 & 6,999 & & 4,160 &, 000 \\
\hline & Supervisi & ,164 & ,038 &, 212 & 4,284 & ,000 \\
\hline & Kompensasi &,- 030 & 079 &,- 019 &,- 377 & ,706 \\
\hline & Kompetensi & ,424 & ,037 & ,609 & $\begin{array}{r}11,51 \\
9 \\
\end{array}$ & ,000 \\
\hline & Motivasi &, 134 & ,058 &, 111 & 2,325 &, 021 \\
\hline
\end{tabular}

aDependent Variable: Kinerja

Tabel di atas dapat dimaknai sebagai berikut. Pada tabel model summary diperoleh skor koefisien determinasi (Adjusted $\mathrm{R}^{2}$ ) sebesar 0,584. Skor tersebut dijadikan dasar penentuan skor koefisien residual analisis regresi linier berganda. Formula yang digunakan adalah $\mathrm{e}=\sqrt{1-\mathrm{R}^{2}} \cdot 3$ Hasil penghitungannya adalah $\sqrt{1-0,584}=0,645$ (jika dipersentasekan menjadi 64,5\%). Inilah

${ }^{3}$ Elazar J. Pedhazur, Mutltiple Regression in Behavioral Rexearch, Explanation and Prediction, (New York: CBS College Pubishing, 1982), hlm. 69. 
besaran skor koefisien residu pada model persamaan analisis regresi berganda.

Rumusan persamaan analisis linier berganda ini didasarkan pada rumusan berikut yaitu $\mathrm{Y}=$ py. $\mathrm{e}_{\mathrm{Y}}+\mathrm{py}_{1}\left(\mathrm{X}_{1}\right)+\mathrm{py}_{2}\left(\mathrm{X}_{2}\right)+\mathrm{py}_{3}$ $\left(\mathrm{X}_{3}\right)+\mathrm{py}_{4}\left(\mathrm{X}_{4}\right)$. Pengisian formula tersebut diambil dari skor koefisien residual untuk py.ey. Skor keempat variabel diambil dari nilai beta $(\beta)$ pada kolom koefisien terstandarisasi (Standardized Coefficients). Ini mengacu pada pendapat, bahwa untuk regresi dengan lebih dari dua variabel eksogen digunakan Adjusted $\mathrm{R}^{2}$ sebagai koefisien determinasi. ${ }^{4}$ Hasil yang didapatkan sebagai berikut: $\mathrm{Y}=0,64,5+0,212+(-0,019)+0,609+0,111$. Skor $\mathrm{F}$ pada Tabel Anova didapatkan sebesar 80,479 dengan taraf signifikansi 0,000 (di bawah 0,05 ).

Dari data tersebut dapat dipahami bahwa variasi variabel kinerja guru PAI SD se-Kota Semarang dipengaruhi oleh variabel supervisi pengawas PAI sebesar 0,212 (21,2\%), variabel kompensasi sebesar -0,019(-1,9\%), variabel kompetensi sebesar $0,609(60,9 \%)$, dan variabel motivasi sebesar $0,111(11,1 \%)$. Sisanya dipengaruhi oleh variabel-variabel residu sebesar 0.645 $(64,5 \%)$, yakni variabel-variabel yang tidak masuk dalam model penelitian.

Atas pemaparan tersebut dapat dipahami bahwa,pertama, skor Adjusted $R$ Square sebesar 0,584 (jika dipersentasekan menjadi $58,4 \%$ ) merupakan besar skor sumbangan pengaruh keempat variabel supervisi, kompensasi, kompetensi, dan motivasi secara simultan terhadap variabel kinerja. Sisanya sebesar 0,645 (atau 64,5\%) ditentukan oleh variabel-variabel di luar model penelitian. Kedua, skor F pada tabel Anova sebesar 80.479 pada taraf 0,000 (di bawah 0,05) menunjukkan bahwa secara bersama-sama ketiga variabel supervisi PPAI, kompensasi, kompetensi, dan motivasi secara signifikan berpengaruh terhadap kualitas kinerja guru PAI SD se-Kota Semarang.

Makna yang dapat diambil adalah berapapun besarnya sumbangan variabel supervisi, kompensasi, kompetensi, dan motivasi dalam mempengaruhi variabel kinerja tetap bermakna. Simpulan ini sesuai dengan rumusan hipotesis penelitian kedua. Berarti, hipotesis yang menyatakan bahwa "ada pengaruh supervisi PPAI,

${ }^{4}$ Duwi Priyatno, Paham Analisa Statistik Data dengan SPSS, (Jakarta: Media Kom,2010), hlm. 66. 
kompensasi, kompetensi, dan motivasi kerja terhadap kinerja guru PAI SD" diterima.

Setelah dicermati dengan seksama, ternyata penerimaan hipotesis tersebut hanya berlaku ketika keempat variabel $\left(\mathrm{X}_{1}, \mathrm{X}_{2}\right.$, $\mathrm{X}_{3}$, dan $\mathrm{X}_{4}$ ) mempengaruhi variabel kinerja secara simultan. Didasarkan pada tabel Anova, skor sig sebesar 0,000 berarti terdapat signifikansi pengaruh keempat variabel tersebut terhadap kinerja. Namun rumusan hipotesis tidak diterima secara menyeluruh ketika diterapkan analisis regresi secara parsial. Hal itu dibuktikan dengan melihat nilai beta $(\beta)$, pada taraf signifikansi masing-masing variabel eksogen ditemukan temuan yang perlu didiskusikan lebih lanjut.

Beberapa temuan tersebut dapat diuraikan sebagai berikut. Variabel supervisi PPAI memiliki nilai $\beta$ sebesar $0,212(21,2 \%)$ pada taraf signifikansi 0,000 (di bawah 0,05 ). Ini berarti variabel supervisi PPAI secara signifikan berpengaruh terhadap motivasi kerja guru PAI SD se-Kota Semarang. Variabel kompensasi memiliki nilai $\beta$ sebesar $-0,019$ (-1,9\%) pada taraf signifikansi 0,706 (di atas 0,05). Ini berarti, kompensasi berpengaruh terhadap kinerja, tetapi tidak signifikan. Nilai negatif menunjukkan hubungan antara variabel kompensasi terhadap kinerja tidak searah. ${ }^{5}$ Artinya, jika persoalan kompensasi bermasalah, maka tingkat kinerja guru akan menurun. Sedangkan variabel kompetensi memiliki nilai $\beta$ sebesar $0,609(60,9 \%)$ pada taraf signifikansi 0,000 (lebih kecil dari 0,05). Ini berarti, variabel kompetensi secara signifikan berpengaruh terhadap kinerja guru. Kemudian variabel motivasi memiliki nilai beta sebesar 0,111 (11,1\%) dengan skor sig 0,21 (di bawah 0,05) berarti signifikan. Maknanya adalah motivasi berpengaruh secara signifikan terhadap kinerja. Ini berarti, hanya variabel kompensasi yang berpengaruh terhadap kinerja, tetapi tidak signifikan. Kesimpulan ini bertentangan dengan paradigma teoritik, bahwa kompensasi berpengaruh terhadap kinerja.

Tabel Koefisien Pengaruh Supervisi Pengawas PAI $\left(\mathrm{X}_{1}\right)$, Kompensasi $\left(\mathrm{X}_{2}\right)$, Kompetensi $\left(\mathrm{X}_{3}\right)$, Motivasi Kerja $\left(\mathrm{X}_{4}\right)$ terhadap Kinerja (Y) secara Langsung

\begin{tabular}{lllll}
\hline Variabel bebas & Nilai $\beta$ & t Hitung & Sig. & Status \\
\hline
\end{tabular}

${ }^{5}$ Jonathan Sarwono, Path Analysis: Teori, Aplikasi, Prosedur Analisis untuk Riset Skripsi, Tesis, dan Disertasi (Menggunakan SPSS), (Jakarta: Elex Media Komputindo, 2012), hlm. 183. 


\begin{tabular}{lcccl}
\hline Supervisi PPAI & 0,212 & 4,284 & 0,000 & Signifikan \\
\hline Kompensasi & $-0,019$ & $-0,377$ & 0,706 & Tidak signifikan \\
\hline Kompetensi & 0,609 & 11,519 & 0,000 & Signifikan \\
\hline Motivasi & 0,111 & 2,325 & 0,021 & Signifikan \\
\hline
\end{tabular}

Sumber: diambil dari out put hasil analisis regresi linier berganda

Dalam bentuk model, penjelasan di atas diformulasikan sebagai berikut.

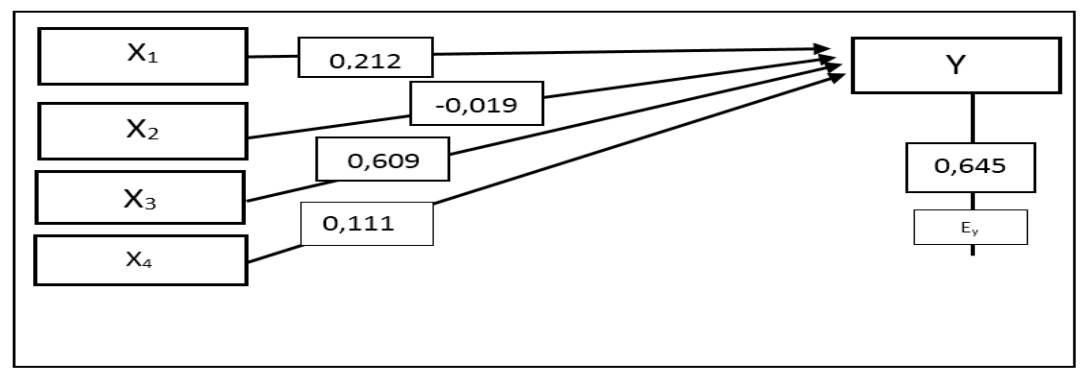

Gambar Hasil Analisis Regresi Linier Berganda dan Nilai Beta $(\beta)$

Gambar di atas dapat dimaknai bahwa variabel kinerja guru PAI dipengaruhi supervisi PPAI $(0,212))$, kompensasi $(-0,019)$, kompetensi (0.609), dan motivasi $(0,111)$, selebihnya dipengaruhi variabel-variabel yang dilibatkan dalam model penelitian sebesar 0,645 . Variabel-variabel tersebut mencakup semua aspek yang mempengaruhi kinerja selain keempat variabel yang dibahas dalam penelitian ini.

\section{Pembahasan dan Implikasi Hasil}

Berdasarkan analisis statistik deskriptif ditemukan bahwa guru responden yang memiliki kinerja sangat bagus adalah sebesar $74 \%$ terdapat pada rentangan 129-156, sedangkan sisanya yakni sebesar $26 \%$ guru responden memiliki kinerja bagus ada pada rentangan 99-128. Berdasarkan data tersebut, tidak ditemukan guru PAI SD yang memiliki kinerja dalam kategori cukup maupun kurang. Itu berarti seluruh guru PAI SD yang memiliki kinerja yang layak dijadikan panutan.

Didasarkan pada analisis regresi linier berganda (determinasi $\mathrm{R}^{2}$ ), ditemukan kinerja guru PAI SD di Kota Semarang secara signifikan dipengaruhi variabel supervisi pengawas PAI, kompetensi, dan motivasi secara serempak. Pemaknaan ini didasarkan 
pada skor F pada tabel Anova dengan skor sig 0,000 (lebih kecil dari $0,05)$.

Namun ketika diterapkan regresi secara parsial, didasarkan pada skor beta dan skor sig, maka ditemukan kesimpulan sebagai berikut. Supervisi memiliki skor beta 0,212 dengan skor sig 0,000. Artinya, supervisi berpengaruh terhadap kinerja secara signifikan. Kompetensi dengan skor beta 0,609 dan skor sig 0,000. Artinya, kompetensi berpengaruh terhadap kinerja secara signifikan. Motivasi dengan skor beta 0,111 dan skor sig 0,021. Artinya, motivasi kerja berpengaruh terhadap kinerja secara signifikan. Sementara peningkatan kinerja melalui variabel kompensasi tidak bisa dilakukan. Hal ini didasarkan skor beta sebesar -0,019 dan skor sig 0,706 (lebih besar dari 0,05). Maknanya adalah variabel kompensasi berpengaruh terhadap kinerja, tetapi tidak signifikan. Sumbangan efektifnya pun memperkuat kesimpulan tersebut, sangat kecil hanya sebesar $0,02 \%$.

Upaya peningkatan kinerja guru PAI SD dengan melibatkan empat variabel eksogen dilibatkan dalam analisis regresi linier berganda. Pembahasan disajikan sesuai urutan variabel dalam model penelitian. Secara runtut pembahasan akan dimulai dari: (1) upaya peningkatan kinerja melalui variabel supervisi, (2) upaya peningkatan kinerja melalui variabel kompensasi, (3) upaya peningkatan kinerja melalui variabel kompetensi, dan (4) upaya peningkatan kinerja melalui variabel motivasi.

Pertama, upaya peningkatan kinerja melalui variabel supervisi pengawas PAI. Variabel supervisi berpengaruh secara signifikan terhadap variabel kinerja, dengan sumbangan efektif sebesar 4,57\%. Berdasarkan data hasil penelitian ini dapat dijelaskan bahwa kinerja guru PAI kondusif dibina dan ditingkatkan melalui variabel supervisi. Kinerja guru PAI membutuhkan faktor eksternal yang bertugas sebagai pengawas, atau supervisor. Pengawas tidak sama dengan penilik, pengawas sebaiknya dimaknai pembimbing atau Pembina. Sebagaimana pendapat Oliva, ${ }^{6}$ "He has been conceptualized as an individual whose primary role is the improvement of instruction, and the curriculum through individual and group assistance to teachers". Kutipan tersebut mengamanatkan, bahwa

${ }^{6}$ Peter F. Oliva, Supervision for Today's Schools, (New York: Longman, 1984), hlm. 561. 
pengawas memiliki peran utama yaitu membantu guru dalam upaya pengembangan pembelajaran dan kurikulum.

Fungsi utama pengawas sekolah mencakup: Pertama, fungsi pembinaan ini merupakan inti fungsi pengawasan. Fungsi pembinaan diarahkan pada guru yang disupervisi, pembinaan situasi, pembinaan pemanfaatan segala dana dan tenaga ke arah terwujudnya tujuan pendidikan dan pembelajaran. Kedua, fungsi penilaian dilakukan dengan mengikuti prosedur dan teknik evaluasi pendidikan. Ketiga, fungsi perbaikan pendidikan dan pembelajaran dan hasil belajar siswa pada khususnya. Keempat, fungsi penelitian koreksi, seleksi, klasifikasi, komparasi, dan interpretasi, hingga dihasilkan konklusi. "All supervisors must be concerned with helping teachers with planning, selection of strategies, and resources, and evaluation". ${ }^{7}$ Pernyataan Oliva ini memperkuat pemahaman bahwa fungsi utama supervisi adalah pembinaan guru. Tujuannya agar guru selalu melakukan usaha perbaikan. Pendapat Oliva tersebut senada teori Briggs, bahwa fungsi utama supervisi bukan hanya perbaikan pembelajaran saja, tapi untuk koordinasi, stimulasi, dan dorongan ke arah terbentuknya guru profesional. ${ }^{8}$

Tanpa pengawas, peningkatan kinerja guru bisa mengalami banyak kendala. Hal ini terkait dengan luasnya cakupan kinerja guru. Lokakarya pendidikan nasional merumuskan cakupan kinerja guru sebagai berikut.

"menguasai bahan, mengelola proses belajar mengajar, mengelola kelas, menggunakan media atau sumber belajar, menguasai landasan pendidikan, merencanakan program pengajaran, memimpin kelas, mengelola interaksi belajar mengajar, melakukan penilaian hasil belajar, menggunakan berbagai metode dalam pembelajaran, memahami dan melaksanakan fungsi dan layanan bimbingan penyuluhan, memahami dan menyelenggarakan administrasi sekolah, serta memahami dan dapat menafsirkan hasil penelitian untuk peningkatan kualitas pembelajaran". 9

Namun demikian, signifikansi pengaruh variabel supervisi pengawas dengan sumbangan efektif sebesar 4,81\% itu menandakan bahwa ujung keberhasilan supervisi selalu ada pada individu

${ }^{7}$ Oliva, Supervision for Today's Schools, hlm. 562.

${ }^{8}$ Piet A. Sahertian, Konsep Dasar dan Teknik Supervisi Pendidikan, dalam Rangka Pengembangan Sumber Daya Manusia, (Jakarta: Rinneka Cipta, 2008), hlm. 21.

${ }^{9}$ Hamzah B. Uno \& Nina Lamatenggo, Teori Kinerja dan Pengukurannya, (Jakarta: PT. Bumi Aksara, 2012), hlm. 68-69 
guru. Pembinaan dan bimbingan seorang pengawas PAI memang penting, namun kemandirian guru tetap menjadi kunci keberhasilan kualitas kinerjanya. Simpulan di atas seirama pendapat Mujib, bahwa "kemampuan belajar mandiri merupakan salah satu langkah penting bagi kemajuan". ${ }^{10}$

Kedua, variabel kinerja tidak secara signifikan dipengaruhi variabel kompensasi. Maknanya, kinerja guru PAI SD di Kota Semarang tidak kondusif ditingkatkan melalui variabel kompensasi. Simpulan tersebut didasarkan pada nilai beta $(\beta)$ sebesar $-0,019$ (negatif) dengan nilai sig 0,706 (lebih besar dari 0,05). Sumbangan efektifnya sangat kecil yakni sebesar $0,02 \%$. Nilai beta $(\beta)$ negatif berarti terjadi hubungan negatif antara variabel eksogen dengan variabel endogen. ${ }^{11}$ Artinya, terjadi hubungan negatif antara variabel kompensasi dengan variabel kinerja. Semakin naik nilai variabel kompensasi, maka semakin turun nilai kualitas kinerja, atau sebaliknya.

Pembahasan kinerja dikaitkan dengan kompensasi biasanya dekat hubungannya dengan persoalan kepuasan, dan imbalan atau gaji. Terkait dengan hal ini, Beck berpendapat, "it is only partly true that 'happy workers are good workers'. The relationship between job satisfaction and performance is considerably less than perfect". ${ }^{12}$ Tidak selamanya benar ada hubungan antara tingkat kepuasan dengan kinerja. Pendapat Beck tersebut dilanjutkan dengan mengutip teori Lawler \& Porter "performance which leads to rewards produces satisfaction with the work and also produces the expectation that future performance will also lead to Kutipan di atas menunjukkan adanya hubungan erat antara kinerja dengan imbalan, asalkan imbalan tersebut bersifat dinamis mengikuti kualitas kinerja.

Padahal kepuasan kerja sangat penting bagi lahirnya produktivitas, kinerja, atau prestasi kerja. Darmawan berpendapat, kepuasan kerja merupakan salah satu bentuk hasil perilaku

${ }^{10}$ Fathul Mujib, Super Power in Educating (Kegiatan Belajar-Mengajar Yang Super Efektif), (Yogyakarta: Diva Press, 2012), hlm. 142.

${ }^{11}$ Duwi Priyatno, Paham Analisa Statistik ..., hlm. 65.

${ }^{12}$ Robert C. Beck, Motivation, Theories and Principles, (New Jersey: Prentice-Hall.Inc, 1990), hlm. 345.

${ }^{13}$ Beck, Motivation, Theories and Principles, hlm. 348. 
karyawan dalam organisasi. ${ }^{14}$ Teori tersebut dapat diterapkan dalam kajian kinerja guru, karena guru juga bagian dari pegawai atau karyawan dalam sebuah organisasi keguruan.

Lebih lanjut, pendapat Lawler \& Porter di atas coba mengaitkan imbalan dan kinerja dengan aspek peluang. Peluang bisa mencakup banyak hal, yakni, penghargaan, dan pengembangan karir. Karena itulah, Sinambela menempatkan peluang sebagai bagian dari tiga dimensi kinerja. Dua aspek lain adalah aspek kemampuan dan motivasi. ${ }^{15}$

Bila dikaitkan dengan kenyataan di lapangan, maka ditemukan beberapa hal terkait dengan penghargaan, gaji, atau kompensasi dalam makna lebih luas. Rivai \& Murni mengatakan,

"jawaban klise, karena gaji guru rendah. Karena gaji rendah, generasi muda yang tertarik menjadi calon guru umumnya bukan para calon terbaik. ...lulusan nonkependidikan yang tertarik menjadi guru dengan mengambil program akta mengajar dapat dipastikan juga bukan lulusan terbaik. Mereka umumnya memilih menjadi guru karena kesulitan mencari pekerjaan di luar profesi guru"16.

Ungkapan di atas seolah menjelaskan, bahwa pemberian kompensasi berupa tunjangan profesi, dan atau tunjangan lainnya hanya akan menimbulkan dilema. Sebagai pegawai mereka mempunyai hak atas kesejahteraan hidup dan penghargaan, namun di sisi lain peningkatan hak tersebut sulit diimbangi aspek kewajibannya. Peningkatan kinerja yaitu peningkatan mutu guru tidak mampu dicapai melalui peningkatan kompensasi. Peningkatan mutu sebenarnya bermuara pada aspek kemampuan dan keterampilan bukan pada aspek kompensasi ${ }^{17}$. Para guru harus bersusah payah dalam memenuhi persyaratan pencairan. Persyaratan yang diberikan cukup rumit. Pemberian tunjangan profesi guru belum dibarengi dengan evaluasi berkala dan sanksi. Adapun kepuasan kerja hanya dikaitkan dengan variabel kompensasi sebaiknya tidak dianggap sebagai titik akhir dalam kinerja individu. Akan tetapi, terdapat

${ }^{14}$ Didit Darmawan, Prinsip-Prinsip Perilaku Organisasi, (Surabaya: Pena Semesta, 2013), hlm. 57.

${ }^{15}$ Lijan Poltak Sinambela, Kinerja Pegawai, Teori, Pengukuran, dan Implikasi, (Yogyakarta: Graha Ilmu, 2012), hlm. 12.

${ }^{16}$ Veithzal Rivai \& Sylviana Murni, Education Management, Analisis Teori dan Praktik, (Jakarta: Raja Grafindo Persada,2010), hlm. 49.

${ }^{17}$ John M. Ivancevich, et.al.,Perilaku dan Manajemen Organisasi, jil. I, (Jakarta: Erlangga, 2006), hlm. 85. 
bukti bahwa kepuasan bersama dimensi lain memainkan peranan penting dalam studi perilaku dan organisasi. ${ }^{18}$

Selanjutnya, bagaimana aspek peluang dalam pekerjaan guru. Terkait hal itu Hoy \& Miskel mengatakan, "the teaching in the elementary and secondary schools has a flat career path, the career is unstaged". ${ }^{19}$ Guru pada sekolah dasar dan menengah memiliki peluang karir yang cenderung datar. Bahkan dikatakan, bahwa guru sebagai sebuah pekerjaan tidak memiliki peluang pengembangan. Hoy \& Miskel menegaskan, "that teachers have no opportunity for advancement in their instructional work". ${ }^{20}$ Dalam hal ini, Rivai \& Murni menandaskan, "karir guru juga harus jelas dan ditetapkan secara objektif. Guru berprestasi secara otomatis akan menjadi wakil kepala sekolah atau kepala sekolah. Wakil kepala atau kepala sekolah akan berkompetisi menjadi kepala dinas pendidikan". ${ }^{21}$ Ironisnya, realitas di lapangan berbicara lain. Penghargaan guru berprestasi hanya dalam bentuk selembar kertas piagam. Tidak sedikit ditemukan seorang dengan predikat guru berprestasi, guru teladan, namun kesejahteraan yang diterima sama dengan guru-guru lain yang tidak mendapat predikat seperti yang dimilikinya.

Sementara guru dikenal dengan "low of pay and low of prestige, but having a significant factor". ${ }^{22}$ Guru biasanya bergaji rendah dan prestisenya pun juga rendah, tetapi guru merupakan faktor penting. Sebuah slogan mengatakan, "tanpa guru sebuah bangsa akan kehilangan generasi berkualitas di masa mendatang". Tanggung jawab setinggi langit, namun gajinya tergolong kecil. Mullin menggambarkan tanggung jawab guru sebagai 'the most critical factors in determining the degree to which their students become educated adults'. Ini merupakan sebuah tantangan bagi dunia pendidikan. Itulah paparan data dan teori yang menyebabkan variabel kompensasi tidak tepat dijadikan variabel tunggal untuk meningkatkan kinerja guru.

Ketiga, variabel kinerja secara signifikan dipengaruhi variabel kompetensi. Maknanya adalah kinerja guru PAI SD di Kota Semarang sangat kondusif ditingkatkan melalui variabel kompetensi.

\footnotetext{
${ }^{18}$ Luthans, Organizational Behaviour, hlm. 246.

${ }^{19}$ Hoy dan Miskel, Educational Admintration, Theory ..., hlm. 257.

${ }^{20}$ Hoy dan Miskel, Educational Admintration, Theory ..., hlm. 257.

${ }^{21}$ Rivai \& Murni, Education Management, Analisis .., hlm. 50.

${ }^{22}$ Mark Mullin, Educating for $21^{\text {st }}$ Century, The Challenge for Parents and Teachers, (New York: Madison Books, 1991), hlm. 106.
} 
Sebagaimana telah diungkap di depan, hakikat kinerja menurut pendapat Whitmore, sebagaimana dikutip Uno \& Lamatenggo adalah suatu perbuatan, suatu prestasi atau apa yang diperlihatkan seseorang melalui keterampilan yang nyata. Selanjutnya Patricia King, menekankan, kinerja adalah aktifitas seseorang dalam melaksanakan tugas pokok yang dibebankan kepadanya. ${ }^{23}$ Dari dua pendapat tersebut dapat dipahami, bahwa kualitas kinerja berbanding lurus dengan keterampilan. Faktor keterampilan merupakan salah satu perwujudan dari faktor kompetensi yang menjadi aspek dominan bagi variabel kinerja.

Atas dasar teori tersebut, kompetensi merupakan variabel penentu dengan porsi sumbangan paling dominan. Ini sesuai dengan hasil analisis statistik dengan melihat nilai beta $(\beta)$ yang besarannya adalah 60,9\% dengan sumbangan efektifnya sebesar 49,4\%. Temuan hasil penelitian ini memang terjadi kesesuaian yang kuat antara teori dengan kenyataan dalam penelitian. Maknanya adalah faktor dominan kinerja guru sebenarnya ada pada persoalan kompetensi. Dengan kompetensi pendidik yang baik, kinerja guru dapat terlaksana dengan baik. Karena hakikatnya, kinerja merupakan penerapan kompetensi untuk mencapai tujuan yang telah ditetapkan.

Makna yang dapat diambil, untuk mendongkrak hasil kinerja guru yang baik, berikan para guru PAI bimbingan teknis yang berkualitas. Bimbingan teknis diarahkan pada peningkatan kompetensi pedagogik dan profesional. Sebaiknya bimbingan teknis PAI tidak hanya berhenti pada tingkat pelatihan. Bimbingan teknis PAI harus dilanjutkan dengan pendampingan. Penekanan pada dua kompetensi tersebut didasarkan pada kebutuhan di kelas. Dua kompetensi itulah yang sejatinya membuat cara guru mengajar disukai atau tidak disukai peserta didik. Kompetensi pedagogik dibutuhkan dalam kinerja proses pembelajaran terkait dengan penguasaan metode pembelajaran. Kompetensi profesional dibutuhkan dalam keberhasilan kinerja terkait dengan penguasan materi ajar. Adapun kompetensi kepribadian dapat dilakukan melalui pendekatan persuasif pengawas atau pelatihan kepribadian. Kompetensi kepribadian dibutuhkan dalam keberhasilan kinerja terkait dengan penanaman aspek spiritual dan sosial. Bahkan di masa mendatang, penerapan kompetensi inti (KI) kurikulum 2013

\footnotetext{
${ }^{23}$ Uno \& Lamatenggo, Teori Kinerja dan Pengukurannya, hlm. 64.
} 
membutuhkan kompetensi kepribadian yang mumpuni. Terkait dengan kompetensi kepribadian, Brookfield mengatakan, "credible teachers are seen as teachers who are worth stricking around because students might learn something valuable from them". ${ }^{24}$ Peserta didik menyukai guru tidak hanya karena penguasaan materi dan cara mengajarnya bagus, namun ketika mereka merasa mendapatkan sebuah nilai atas kehadiran guru di kelas.

Keempat, kinerja kondusif ditingkatkan melalui variabel motivasi. Ini berarti upaya peningkatan kinerja guru PAI tidak bisa melupakan variabel motivasi. Simpulan tersebut dapat dijelaskan dengan menggunakan teori Mitchel yang mengatakan, kinerja sama dengan perkalian antara variabel kemampuan dengan variabel motivasi. ${ }^{25}$ Dalam matematika berlaku suatu hukum, perkalian akan menghasilkan nilai positif, apabila yang terlibat dalam perkalian adalah angka-angka positif. Bila dalam perkalian terdapat satu angka negatif, maka hasilnya pasti negatif. Demikian pula, kinerja akan semakin positif bila didukung kemampuan (kompetensi) dan motivasi yang positif. Untuk menghasilkan sebuah kinerja berkualitas tinggi, dua variabel kompetensi dan motivasi harus kondusif. Bila salah satu variabel tersebut kurang bagus, maka upaya peningkatan kinerja dapat mengalami kegagalan.

Dalam kasus penelitian ini, variabel kompetensi terbukti secara signifikan mempengaruhi kinerja. Ketika hasil analisis menunjukkan bahwa variabel motivasi juga berpengaruh terhadap kinerja secara signifikan, maka teori Mitchel nyata terbukti. Artinya adalah kinerja guru PAI akan semakin bagus karena didukung tingkat kompetensi dan kualitas motivasi kerja bagus.

Penjelasan ini sekaligus membantah bahwa faktor usia dan senioritas menjadi penghalang peningkatan kinerja. Berdasarkan data pada tabel 4.2 halaman 134 ditemukan bahwa 59\% guru PAI SD se-Kota Semarang termasuk kategori tua, bahkan hampir purna tugas. Tabel 4.1 halaman 134 juga menegaskan, bahwa 68\% guru PAI SD memiliki masa kerja di atas 25 tahun. Hanya sekitar $15 \%$ guru yang tergolong usia muda. Guru senior ternyata masih dapat dikembangkan dan diberdayakan.

${ }^{24}$ Stephen D. Brookfield, The Skillful Teacher on Technique, Trust, and Responsiveness in The Classroom, (San Fransisco: Jossey-Bass, 2006), hlm. 56.

${ }^{25}$ Sinambela, Kinerja Pegawai, Teori .., hlm. 9. 
Data analisis deskriptif menerangkan,motivasi kerja guru PAI SD se-Kota Semarang $81 \%$ dalam kategori sangat tinggi dan $17 \%$ tinggi. Besaran angka kedua persentase tersebut menjelaskan, bahwa hampir semua guru PAI SD memiliki semangat kerja sangat tinggi. Demikian pula, data analisis deskriptif variabel kinerja menjelaskan, 74\% guru PAI SD memiliki kinerja sangat bagus, dan sisanya yakni 26\% memiliki kinerja bagus. Tidak ditemukan ada guru PAI yang kinerjanya cukup dan atau kurang bagus. Hasil analisis deskriptif mempertegas bahwa variabel motivasi berpengaruh secara signifikan terhadap kinerja. Nilai beta variabel motivasi sebesar 0,111 (11,1\%) dengan skor sig 0,021 serta sumbangan efektifnya sebesar 1,2\% (lihat tabel 4.16 halaman 169) merupakan bukti kebenaran simpulan tersebut. Pemupukan motivasi yang terbaik adalah melalui penguatan nilai agama Islam. Terkait hal tersebut Luthans mengatakan, "penting untuk mengintegrasikan berbagai nilai agama dan sikap dengan pendekatan yang kondusif untuk sukses dalam ekonomi pasar yang berkembang pesat saat ini". ${ }^{26}$ Tingginya motivasi kerja guru turut menentukan tingkat kinerjanya.

Variabel residu sebesar 0,645 (atau 65,4\%) menyiratkan sebuah makna bahwa kinerja dipengaruhi sebesar $65,4 \%$ oleh variabelvariabel yang tidak dilibatkan dalam penelitian. Kesimpulan ini didukung oleh hasil riset disertasi Brotosedjati (2011) bahwa kinerja (pengawas) dipengaruhi intensitas mengikuti diklat, pengalaman kerja, beban kerja, sistem penilaian, kompetensi kesupervisian, dan motivasi kerja. Bahkan Donelly dkk mengatakan, kinerja individu dipengaruhi enam faktor yaitu harapan mengenai imbalan, dorongan, kemampuan, kebutuhan dan sifat, persepsi terhadap tugas, imbalan internal dan eksternal, serta persepsi tentang tingkat imbalan dan kepuasan kerja. $^{27}$

Adapun implikasi hasil penelitiannya adalah sebagai berikut: Pertama, kinerja guru PAI SD di Kota Semarang dapat ditingkatkan melalui variabel supervisi. Ini berarti, supervisi pengawas PAI sangat penting bagi peningkatan kinerja guru PAI SD. Karenanya, peningkatan pelayanan dan pembinaan pengawas kepada para guru sangat menentukan kualitas kinerjanya.

\footnotetext{
${ }^{26}$ Luthans, Organizational Behaviour, hlm. 296.

${ }^{27}$ Sinambela, Kinerja Pegawai, Teori .., hlm. 11-12.
} 
Kedua, kinerja guru PAI tidak dapat ditingkatkan hanya melalui peningkatan kompensasi terutama berkaitan dengan kesejahteraan, Hiruk pikuk guru dalam pengurusan pencairan tunjangan profesi terkadang tidak berhubungan dengan peningkatan kinerja. Bahkan tidak sedikit guru meninggalkan jam mengajar, lantaran mereka sibuk melengkapi persyaratan pencairan, belum lagi tingkat kecemasan terhadap kemungkinan tidak cairnya tunjangan profesi, lantaran terkendala banyak hal, misalnya, kurang jam mengajar, mata pelajar tidak linear, berkas kurang lengkap, dan sebagainya.

Ketiga, kinerja guru PAI SD sangat kondusif ditingkatkan melalui peningkatan kompetensi. Sumbangan efektif variabel kompetensi sebesar49,4\% jelas menunjukkan, aspek penting peningkatan kinerja guru terletak pada aspek kompetensi. Kompetensi pedagogik, profesional, dan kepribadian harus dijadikan poin utama pada setiap pembinaan, pembimbingan, pendampingan, workshop, dan pelatihan guru. Pelatihan yang dengan kompetensi pendidik hendaknya jangan hanya formalitas.

Keempat, kinerja guru PAI SD kondusif ditingkatkan melalui variabel motivasi. Ibarat mobil, kinerja melambangkan gerak mesin, roda, dan sistem penggerak yang lain, dan motivasi melambangkan premium dan sopirnya. Tanpa premium dan sopir, mobil tidak akan dapat berjalan. Artinya peningkatan kinerja guru menjadi kurang efektif tanpa kualitas motivasi kerja yang bagus.

Kelima, upaya pembinaan dan peningkatan kinerja guru PAI SD harus melibatkan variabel-variabel yang tidak diikutsertakan dalam penelitian. Variabel-variabel tersebut meliputi: variabel intensitas mengikuti diklat, pengalaman kerja, beban kerja, sistem penilaian, kompetensi kesupervisian, model kepemimpinan kepala sekolah, latar belakang pendidikan, dan kondisi ekonomi keluarga.

\section{E. Penutup}

Secara simultan variabel supervisi pengawas PAI, kompensasi, kompetensi, dan motivasi kerja berpengaruh secara signifikan terhadap kinerja guru PAI. Simpulan tersebut diperoleh dari pemaknaan skor pada kolom adjusted $R^{2}$ sebesar $0,584(58,4 \%)$ menunjukkan besaran sumbangan pengaruh, dan skor sig 0,000 (lebih kecil dari 0,05). Artinya peningkatan kinerja guru PAI sebaiknya melibatkan keempat variabel tersebut secara bersamaan. 
Secara parsial ditemukan bahwa variabel supervisi berpengaruh terhadap kinerja secara signifikan. Skor beta-nya sebesar 0,212 $(21,2 \%)$, dan skor sig nya 0,000. Variabel kompetensi berpengaruh terhadap kinerja secara signifikan. Skor beta-nya 0,609 (60,9\%) dan skor sig 0,000. Variabel motivasi berpengaruh terhadap kinerja secara signifikan. Skor beta-nya $0,111(11,1 \%)$ dan skor sig nya 0,021 (lebih kecil dari 0,05). Sementara variabel kompensasi yang berpengaruh terhadap kinerja, tetapi tidak signifikan. Skor beta-nya $-0,019$ (negatif) dan skor sig nya 0,706 (lebih besar dari 0,05). Ini berarti upaya peningkatan kinerja guru dengan melibatkan variabelvariabel eksogen secara terpisah akan berdampak pada kurang maksimal hasilnya.

\section{Kepustakaan}

Beck, Robert C., Motivation, Theories and Principles, (New Jersey: Prentice-Hall, 1990).

Brookfield, Stephen D., The Skillful Teacher on Technique, Trust, and Responsiveness in The Classroom, (San Fransisco: Jossey-Bass, 2006).

Brotosedjati, Soebagyo, Pengaruh Diklat, Pengalaman Kerja, Beban Kerja dan Sistem Penilaian Terhadap Kompetensi, Motivasi Kerja, dan Kinerja Pengawas TK-SD se eks karidenan Surakarta, Disertasi, (Semarang: Unnes, 2011).

Darmawan, Didit, Prinsip-Prinsip Perilaku Organisasi, (Surabaya: Pena Semesta, 2013).

Hoy, Wayne K. dan Miskel, Cecil G., Educational Admintration, Theory, Research, and Practice, (United State: McGrawhill, 1991).

Ivancevich, John M, et al., Perilaku dan Manajemen Organisasi, Jilid I, (Jakarta: Erlangga, 2006).

Lipham, James M., Rankin, Robb E., Hoeh Jr., James, The Principalship, Concepts, Competencies, and Cases, (New York: Longman, 1985).

Luthans, Fred, Organizational Behaviour, terj. Vivin Andika Yuwono, dkk. (Yogyakarta: Penerbit Andi, 2006).

Mujib, Fathul, Super Power in Educating: Kegiatan BelajarMengajar yang Super Efektif, (Yogyakarta: Diva Press, 2012). 
Mullin, Mark, Educating for 21 $1^{\text {st }}$ Century: The Challenge for Parents and Teachers, (New York: Madison Books, 1991).

Oliva, Peter F., Supervision for Today's Schools. (New York: Longman, 1984).

Owens, Robert G., Organizational Behavior in school, (New Jersey: Prentice-Hall, 1970).

Pedhazur, Elazar J., Mutltiple Regression in Behavioral Rexearch, Explanation and Prediction, (New York: CBS College Pubishing, 1982).

Priyatno, Duwi, Paham Analisa Statistik Data dengan SPSS. (Jakarta: Media Komputindo, 2010).

Raharjo, Rahmat, Inovasi Kurikulum Pendidikan Agama Islam: Pengembangan Kurikulum dan Pembelajaran, (Yogyakarta: Magnum Pustaka, 2010).

Rivai, Veithzal \& Murni, Sylviana, Education Management, Analisis Teori dan Praktik. (Jakarta: Raja Grafindo Persada, 2010).

Sahertian, Piet A., Konsep Dasar dan Teknik Supervisi Pendidikan dalam Rangka Pengembangan Sumber Daya Manusia, (Jakarta: Rinneka Cipta, 2008).

Sarwono, Jonathan, Path Analysis, Teori, Aplikasi, Prosedur Analisis untuk Riset Skripsi, Tesis dan Disertasi (Menggunakan SPSS), (Jakarta: Elex Media Komputindo, 2012).

Siagian, P, Sondang, Manajemen Sumber Daya Manusia, (Jakarta: Bumi Aksara, 2007).

Sinambela, Lijan Poltak, Kinerja Pegawai, Teori, Pengukuran dan Implikasi, (Yogyakarta: Graha Ilmu, 2012).

Sofanudin, Aji, Mengukur Kompetensi Guru PAI Tersertifikasi dan Belum Tersertifikasi, Laporan Penelitian, Semarang: Balai Penelitian dan Pengembangan Agama, 2012).

Sukandar, Undang-Undang RI Nomor 14 Tahun 2005 tentang Guru dan Dosen, (Jakarta: Pustaka Candra, 2006).

Uno, Hamzah B., \& Lamatenggo, Nina, Teori Kinerja dan Pengukurannya, (Jakarta: Bumi Aksara, 2012). 